\title{
The contradictions of development
}

\section{Primitive accumulation and geopolitics in the two Sudans ${ }^{1}$}

Clemens Hoffmann

\section{Introduction}

The recent opening ceremony of the so-called Lamu Port and Lanu Southern Sudan-Ethiopia I'ransport (orridor (LAPSSET) has laid bare yet again the inberently contridictory nature of post-colonial developmene. The mega project creates a new East African transpont considor connecting land-locked South Sudan and Ethiopia with a 32-berth deep-seal water facility at the Indian ( Recain. Among a varrety of development objectives in the pirticipating countries, the project is designed to offer an alternative export route for South Sudanese crude oil. Since its independence, the 'worle's newest conntry' has been at loggerlouds with its former ruler in Khartoum over a transfer fee for using the pipeline, refineries and port facilities for the traditionnl export route through the Red Seil. Yet even though the project, if implemented, will have a trencendously positive effect on South Sudiun's development potential, locill communitics in Lanu chain they have not been consulted over the development of the UNES() () heritage site into a major infrastructure bub (( Bari 2)12; York 2()12).

This dispute reflects but one of the imminent coneradietions South Sudin faces in its effort to catch up. (loser to bonc, loreign I)irect luvestment (FID) is sought to develop the post-war economy

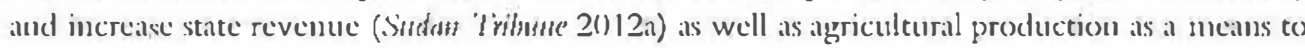
boost food security (Lupai 2(1)12). This strategy is influcutial across Africa (Bush at at. 2(1)11: 188-9), but the Hon of Africa appears to be a special calse dec to its high vuluerability to food insecurity (USAll) : and Fumine Early Wanning System Network 2(1)12). In fact, the UN World Food ?rogrammo (WIPP) expects to fied up to balf of South Sudiun's population in 2(1)12 (WFP' and FA() 2(1)12). Meisured by these objectives, the hand invesement activity in South Sudin to this day has not yielded greit resulte- Accanisitions hacked good prictice with regards to comnunity consultation and envirommental impact assessments (1)eng 2()I I), while most transactions appear to remain merely speculative (Mosley 2(1)12). It is not only food inseconity that remains a piranomont issue for the Republic of South Sudian, however, but also the long-established need to divervify the cconomy affier the dispute with the North has led to the less of all oil revenues at a eime when 'intermal" and 'external' conflicts spiral and put heavy burdens on the stretched budget. 
In many ways, however, the contradiction between community rights and agricultural development, geared to increase production, either to meet local demand or to increase state revenuc as an export commodity, is not unicue to South Sudan in 21)12. Sudanese history features a weilth of examples where contradictions turned into confrontation and anned struggle. Prior to the discovery of oil, the comery's conflict-ridden trajectory from triaditional modes of subsistence $(0)$ a modern capitalist regime of accimulation has by and large evolved "on the ground" around transforming land and labour into productive sources of surplus value, thought to fill inaginary A fricin and Arab breadbaskets respectively. Many conflicts and maybe even elae division itself can be seen as a long-term result of this process of 'mal-integration' inter the capitalist world economy (Ayers 2()10). Despite the new South Sudancese Lind Act and Land Policy explicitly addressing some historic conflict dymanics around land by inscribing John (iarang's sloginn of 'land belonging to the people', some intrinsic contradictions should be on Juba's radar.

This chapter will provide an overview of historical and contemporary dymamics and transfonmations leading to these development contradictions. The core subject matter of this analysis is the precess of appropriation and primitive accumulation of previously uncomuneditised productive resources, notably liand, labour, cappital and, in the casce of agricultural development, water. However, instead of merely identifying 'dispossessed' classes and 'appropriating' angents whose actions (or inactions) are assumed to be solely based on al self-interested profit motive, this chapter will forcher explore the complex set of global structural relations informing locial agents and enderlying their actions. While the literature has usefully reflected on erensmational global markets as a driving force behind such processes, not:ably in the form of foreign cappital, sometines competing strategic orientations of difficrent state powers - in other words, gecopolifical relations and the ways in which they interningle with market relations - have received less attention in the analysis. This chapter will try to remedy this shortcoming in the Sudanese context. J'his culphasis on the dualistic structure of world politics consisting of global markets and an interstate system should not be read, however, as an attempt to diminish locial, individual angency in the process, or as reducing them (o) passive executors of global or geopolitical imperatives. Equally, it is not intended to sec any of these spheres of social interaction as selfecontained and murclated to one ansother. Rather, this chapter ams to take into account regiomally and historicially specific social relations between macro-structures and local agents and, in doing so, provides a nuanced andalysis of the process of acceumulation in Sudan and South Sudan.

\section{Primitive accumulation, development and the state}

\subsection{The concept of primitive accumulation}

Altheugh the concept of 'previous accumulation' was first developed by Adam Simith (1982), it ganed more prominence in Karl Marx's historicial materialist re-conceptualisiation as the process of 'prinitive accumulation'. This is for Marx the historical process whereby producers arc divorced from their meins of production, notably the enclosure of land in 1 (oth-century Eng land (Marx 1981: (h. 26). This act of dispossession of subsistence fanmers from their primary means of production is, however, not seen as a 'natural' oceuncence, but as a precondition, instituted by extrateconomic - i.c. political and violent - meinss, so that market relations can engage in a procexs of impersomal, marketbased appropriation later (13renner 1985; Wood 1999). It involves not only the commodification of land via enclosing commesns, but also the transformation of peisants inte waged agricultural labourers. The essential objective of this process is the commodification not only of land but of all factors of production, turning land, capital and labour into marketable geods, generating the specific form of social reproduction 
known as capitalism. Marx's own preoccupation was with the transformation of subsistence producers into wage labour, or the proletarianisation as the essential intermediary step in generating the future revolutionary class. In that sense, he was not morally averse to the process, and in fact saw it as part of a necessary, if violent, transfommation. However, far from being a finite process whereby productive fictors, once conmodified, remain in the market splaere, primitive accumulation has to be understood more as a permancut, infinite process necessitated by ciapitalism's expansion, and the need to overcome its inherent contradictions and to maintain the separition of producers from productive factors (1) Angelis 2()(1)4; Luxemburg 1951). Even though Maxx specifically refers to colonialism as one outcome of this process, expansion does not necessarily have to be seen as a temitorial process only, but cinn involve constant transformations, in particular with regards to the changing nature of labour-capital relations within the 'global north', 'north-south' relations as well as incomplete transitions within the 'globil south' (Harvey 2()(1)3).

Given the Marxist leanings of many Third World mationalist revolutionary movements, including the Sudin People Liberation Movement (SPLM) during the initial phases of the struggle in 1983 (13erhanu 2()11: 8.3), ${ }^{2}$ this concept has also found inroads into the development literature (Amin 1977). However, the major shortcoming in applying this concept to South Sudan is its presumption of i direct, stationary relation between producer and land. Dispossession in the transition from foudalism to capitalism in Europe thus required the extraction of direct producers from the land. In the casc of more mobile forms of subsistence, like pastorialism or shifting cultivation, the opposite transformation is recpuired (and pursted): namely, the setthing of populations is a precondition for the commodification of land and labour. "Primitive accumulation' in Africin is, thus, not always comparable to the processes in Europe. Apart from seteling mobile populations, it also implies the monopolisation of land use and the dispossession of producers from their means of social reproduction. The role of states in general and postcolonial states in particular, rather than private entrepreneurship, is crucial in driving this socioeconomic transformation. In other words, colonial administrations as well as post-colonial state formations introduce capitalist social relations. Though they never introduce an ideal-typical European 'mirsor' image, transfornation always happens via a process of violent dispossession, rather than developing organically driven purely by an indigenous entrepreneurial spirit. ${ }^{3}$ This also includes the recognition that government accumulation can still be cirried out with the objective of commoditssation, even if no privitely owned capital is initially involved. Private ownership docs not per se constitute a condition for commoditisation, as the state is fecquendy the appropriator par excellence in post-colonial contexts - itself appropriated by private interest, local, national, global or simply intangible. Hence, different geographical instances of accumuliation and dispossession are heterogencous while historical and contemporary dymanics are highly complex based on diffirent social formations producing different forms of resistance (Giassman 2()()6: (22)). In stm, the core premises of this analysis are that (a) accumulation and dispossession arc a priori extra-ceonomic, political processes, and (b) that they arc necessarily permunem in scope due the enduring labour-capital dialectic.

\subsection{Primitive accumulation in the two Sudans}

\subsubsection{Sudan}

A bricf look at Sudan's history reveals many instances of appropriation and dispossession, both in its colonial as well as its posfcolonial history (c.g. Abdclkarim 1992; Ayers 2()1(1)). Here, the most feepuently cited examples are the (iezira and Ciedaref irrigated agricultural schemes, which introduced mechanisation and vanying forms of mostly castral waged labour while strengthening 


\section{Clemens Hoffmann}

the locial merchant (or circulation) capital. 1)espite being institutionalised by the colonial masters and being rem by private operaters, the Sudanese state in its diffierent articulations remained the key agent of development as all land remained de jure public property (Bannete and Abdelkarim 1991). Sociologically, however, what Ayers calls Sudan's 'Inal-integration' into the global political economy prodeced "a dependent class of "local resource extractors"” (Ayers 2()1(): 16.3), a local appropriating capitalist chass, who intensified resource extraction in Sudan in accordance with a global regime of growth and accumulation. (On the flipside, they served not only to deplete Sudan's ecology, but also to impoverish the vast majority of Sudan's population by making them low-income wage einners.

Primitive accumulation in Sudan arguably has a long tradition, though this hiseory is rather complex and uneven. During the Turco-Egyptian and Anglo-Egyptian regimes, forms of private landownership were established, while private 'foreign' capital (Cireck and Syrian) had started penetrating Sudanese agriculture and semi-feudal landlords were established. These were usually close to political power both prior to and after independence. This also implied integrating into a global economy, appropriating land, labour and subsecpuently surpluses together with European formal or infonmal colonisers. This was particularly visible in the export-oriented cotton production in Cihezira. In fact, cotton exports made for a trade surplus in the first years of the nowadiays debt-stricken independent Sudan. As a result, it was the only post-colonial Arab state not declaring a large-scale land refonn with independence (A wad 1971: 212), simply becane it didn't appear necessany to the established beneficiaries of a system of global wealth extraction. In other words, private and semi-statal forms of land aceptisitions, but also the viosent appropriation of free and unfece habour, had already developed as a 'tradition' in colonial and further inte post-colonial Sudan. However, its uneven and partial nature had equally allowed pre-capitalist forms of subsistence, in particular nomadic livelihoods, to survive.

The crecial turning point in trying to close these gaps was President Ninnery's 197() Unregistered Land Act, declaring all unclaimed land (i.e. unless claimed by investors) state propenty. This modern-day forn of enclosure established the legal basis for large-scale land accuisitions by Nimery's socialist-labelled regime. While it was by no means the first stech example, it certianly constitutes a highlight in the uneven development of land policy in post-colonial Sudan. Modenusiation and land reform came packaged in an agenda of 'Sudanism' which was meant to overcome traditional, or rather factional, rule. Nimery's administrative refomms replacing the 13ritish system of 'Native Administration' were meant to implement a more centralised administration further facilitating land use. In reality, it represented only another step in the incom=plete transition fom traditional to modern authority (cf Mamdani 2()()9: 173), creating whate Mandani cills many Sudans within a single state (ibid.: 174).

These were necessiry steps to implement the 'Arab Breadbasket' strategy, geired to supply food to the Middle East while raising national income through crops expores. It rested on ehree pillars, namely Sindinese land and resources, A rab capital and Westem know-how. The 'know-how' cimne fiom Washington as early as 1968, when the Mechanised Fanning Conporation (MFC) was established upon recuest fiom the World bank to secure loans and facilitate credit to farners (Sulinsan 1994: 16). Subsecguent expansion of mechansed fanning was further finded by the World Bank under the MFC umbrella. The International Monetary Fund (IMF) structunal actjustment programmes continued the encouragenent of growing export-oriented cash crops rather than establishing food security at home. This resulted in the slow loss of self-sufficiency for Sudin, once ruming a trade surples, and applied not least to the cultivation of wheit, which was considered unsuitable for an export-led growth regime by agricultural specialists. The Arab/Africin food basket idcology, in conjunction with the influx of furcign capital politically facilitated by the Washington Consensus, continued to open the Sudanese market and production. 
bomestically, the Unregistered Land Act conncided with the 1972 open door or infirnt policy which had codified Sudan's dependence sn foreign capital (Elmur 2()()8: 4(1)). Investment into the Arab Breadbasket was not only politically diven by the food strategy of (iulf states but also finsucially, fuelled by the need to recycle OPEC petro-capital, especially after the 1973 oil crisis had celt of Western markets. However, expansion was driven not only by the imperatives of a global political economy, but also by the rapid soil depletion the somewhat thougheless cultivation of newly introduced cash crops had cansed. Expanding the frontiers of cultivation and eventual envirommental degradation led to more land conflict, notably in the Nuba monutans, southern l3lue Nile and eastern Sudan (Ayers 2010); Suliman 1999a, 1999b, 1999c). In short, through unstustainable firming, capitalist expansion was dependent upon teritorial expansion as long as the economy would remain focused on primary commodity export. This led not only to increased prices and depressed wages but also to the continuation of (unsustainable shorttennist' cultivation practices. Thesse fictors co-deternumed the ecologic and economic crisis still ongoing today, which is characterised by an enduring curtent account deficit, only disropted by - in retrospect - a short era of oil riches.

After Nimery's fill, the 1986 interregumum of parliamentary democracy led to the rise of Islamist partics, possibly in reaction to socio-economic developments. In 1989 the continued economic failure led to anotizer coup by an impatient 'nuthless business and funance segment of eluc riling elite' (Suliman 1994: 19). The finance segment was based on an emerging islanic banking sector majority-owned by (iulf investors. The Faisal Islamic 13ank, for example, is 6(1)\% owned by foreign investors. Not only did Islamic banks enjoy tux breaks not available: to other banks, but as a result of politically engineered privileges the lending and business practices of islanic banks 'revolutionised access to credit, and wrested the virtual monopoly of this vital sector from privileged groups (many of whom were of foreign extraction)' (Elmur 2()()8: 7()). In that sense, it was, according to Eluur, the single most important fictor explaining the rise of the Islamist movement (ibid.). Its success in megotiating political and tax concessions from the state meant that it enjoyed a competitive edge over Sudan's established banks, cuickly outgrowing them. War, in tunn, hanned primary production in Sudan and led to increasing economic pressure on the Khartom bourgeoisic (or Jellaba), leading to a consolidation of mercantile capitalist activity with islamic finance, firelled by a greswing oil income in the Sudanese capital. Accumulated capital, in part due to the endemic state of political instability, moved abroad, however, along with skilled labour and upper middle-class urban population throughout the 1980)s and 199()s, destined for oil-producing Arab statess and Europe.

This consolidation of a strong class alliance, based in Khartoum, between agricultural capital, a merchant bourgeoisic and political elites was in fict cuite similar to previous Umuma and Maldi administrations. Nimery's socialist experiment can be secen as the exception to the aile here. What made the NCl's regime difficrent from its predecessors, though, was its mech more pronounced Islamist agenda. Second, not only capital accumulated in the agricultural sector but also a petro dollarfuelled islamic finance became major pillars for the regime (Elhiraika 1996; Khalecfa 1993).

However, as capital wants to see guick retunss on investments, the rapid and violent replacement of more sustainable fonns of production in a subsistence economy by forns of production ancenable to surplus extraction continued. Not only did this perpetuate social strain and conflict, it also exhausted ecosystems. The latest two instaments of these policiess are the outsourcing of production in (iczira to Egyptian state investors, dispossessing fanmess there (Ali 2(1)1(1)), and the hydro-engineering and irrigation developments in north Sudan and Blue Nile.

Agricultural developments around the Merowe multi-puxpose dam project, for instance, have led to the displacement of many Manasir, Amri-Handab and Nubian people far from their ancestral lands. The creation of new communitics around new production areas is then marred 
with a policy of homogenisation in the fiorm of lslannisation. Arguably, thus, Hooding current and funare hydro-congincering and agriculeural projects fislow the punpose nost only of increasing production, but also of transforming livelihoods, expandling mechanisation along with conerolling wage-labour relationss. In sum, this amomes to what some call 'demographic engincering' (1 tashim 2(10)), some of which is said en be achieved by scetling ligyptian fanmen in the Sudan

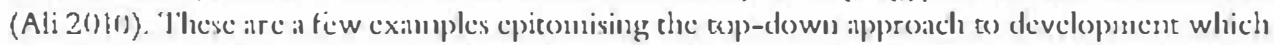
explains es some degree the various complex and persistente contlicts in the comery. However, it is



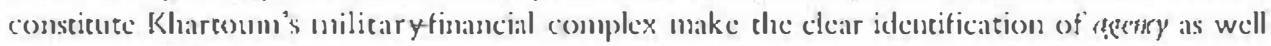
is sineremes difficult.

\subsubsection{South Sudan}

Compared te the vast history of fitiled, unsustinable or conflict-ridden igriculeural developmente in Norel, Sitdin, South Sudan has secen liete to no such isvestunceses or developmene in genctal, though pleney of contlict. Largely owing to a policy of neglece bue also through decaldes of alunost minterrupted conflice : and hestilities, large agriculeural schemes are albsent. 'This makes the newly fisunded Republic of South Sudan a peculiar place, which is markedly differene not only from ies merchern seighbour but also from its East African meighbours Kenya, Uganda and Ethiopia, South

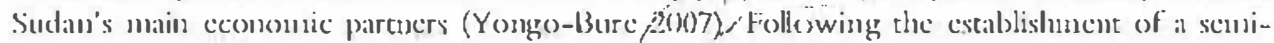

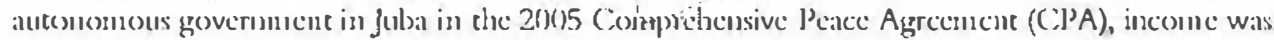
largely generated by oil revenues, which translated inte one of the highest per capita inceneses on the continent, comparable to that of South Africal. Jaradoxically, owing to the legacy of Africis's longest civil war, it also features one of the lowest hum lan development indicess as well as being severely food insecure in a region vulueralbe to the effects of weither extremes, such as deughts and foods.

Agricultural production and rural livelihoods remain by and large based on tradition l because of its variable clinutate, both spatially as well as cemporally, South Sudan traditionally foitures changing land-use patterss and a highly mobile population. Livelihoods are based on shared land usc, which is the rule rather the exception. This alsio includes the farming areas of the so)called lapuatoria (ireen Belt, where shifting cultivation is common. Arguably, these conditions don't lend themselves casily en the intreduction of a Western-style private property regime, let alone large mechanised schemes. While enerencloed in local tradietion, shared land-use practice was never entriely conflicefiec and miny use rightes were negetiated using differing levels of violence. (:urrently, however, it leads eo high levels of violente and scores of casualtics. 1)ecades of war hive damiged old confliceresolution mechinisms along with traditional authority while having proliferated fire arms. Several campaigns of disarmanmene have only becon partially successfill so fir (Schomesus and All:u 2()|(1): I()). Thus, confliet and displacement have bed to the disoricustation of wide parts of the population and a general deterioration of the traditional social order, which has only very inconsistently becon replaced by modern state strictures. fo short, Souch Sudan has thus fier firled to inplement Max Weber's famously defined modern state as "a lmumin community (that) successfully chams the monopoly of the legitimate use of physical force within a yiven territory' (Weber (9)9): 7k).

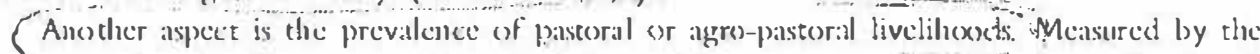
outpert of marketable commoditics, this is by and large a non-preductive sector. Farming is more tradicionally reoted in (ireater licuatoria, where soils are thought en be more fertile, but cven here the legicy of contlict has destroyed many tanditional fanning vills. As far as land-tse patecrus ane concerned, this does not necessarily lead to more stationary livelihoods more adaptable to capitalist modes of production. ()n the onc hasd, eontlice has broughte many 
pastoral conmmunities to the region, incereasing pressure on existing land and water resources. (), the other hand, farners have tjaditionally adhered to shifting cultivation. Lastly, if existing firms produce beyond subsistence levels, marketing skills are insufficient and uecessiry infiastructure for producer's access to the market is either poor or non-existent, so that food supply remains dependent on imports from Kenyal and Uganda as well as WFP handouts.

(Current South Sudaucsc developmente and agricultural policies are trying to attract Fil) for the purpose of ferod production. Beyond local consumption, President Kiir and Vice-President Machar poined to the potential export orientation of production when noting South Sudius calpability of becoming the regional food basket, with 'the cutire world bencfiting it' (Umal 2()1(1). Notions of Sotuth Sudan as the region's breadbasket depend on the assumption of 'resource abundance', notably abundauce of land (Lupiai 20)1 1). However, the seissonal use of land precludes such an easy and somewhat foregonc conclusion. Awareness of elue historical trajectory of Sudims's 'n ual-integration' into the world economy is therefore essential when these policies are implentented.

Having said that, there are various obvious differences between north and South Sudiun with the latter being incorporated inte a regional East Africin economy, ratlace than develejpiing a dependency on petro-dollars for its agricultural development. Ficpually, it is not exposed tor the sance clinstic conditions as the north and mighte, therefore, be capable of intreducing mectanised agriculture in a more sustamable mamer compared to the unsustaimable scluemes that have led to envirommental degradation uorth of the new border. Partly threugh historical experience, partly through the current debates about land grabs, the South Sudiunesc leadership is not unit ware of potential problems (Nhial 2()()8). It aims to introduce legal safeguiards agaiust nonproductive investments or those only directed by high yields rather than food security, such as carbon sinks and biofucls. Equally, South Sudau might not be subjected to a similarly rapacious investment regime of Istamic/Ciulf finance, even though the activitics of a venture capital finu like the farch (iroup or the private Egyptian but statedominated (Gtadel group), as well als other investment activities, give rise to some concern (1)eng 2()11).

\section{The nation, the global and the geopolitical}

\subsection{Clobal capital accumulation}

Much of the literature on liand grabs hals rightly pointed to the issuc of 'global' market forces as the core agene behind the process of land grabs across Africal, which, cos some, constitutes a new wave and new fonus of 'primitive accumulation' (Sissen 2()I(1)). Though some disigrec that the observable forms of land investment in South Sudau ciun be secu as part of the pan-Africiun phenomenon of liand grabs (Mosicy 2012), the govermment of South Sudin's repeited rhetorical commitment to privite investors sas the key meians of development in the new country begs some questions, not least beciuluse it also leaves the notion of al 'right to self-determination' incomplete at best. Inflow of privite ciapital to compensiate for lost oil revenue might help South Sudan in its determination to an independent destiny vis-à-vis the north; however, it creates new forms of dependencies, potentially leading to a damaging foreign debt cycle as was showciased in uorth Sudiul. In that seuse, the involvement of globil commodity markets and the long-term impact of the calpital flight fiom the sub-prime crisis" on rising feod pizces can be secu as new formss of a pluenomenon well known to Sudiun. In other words, lind grabs are not only a contemporary pluenomenon. They are but the latest step in a long historical legacy of primitive accumulation happening across the globe with implications for both Sudius. 


\section{Clemens Moffmann}

As was describs.ed above, Sudan's de:velopment and in particular its agricultural development were: tightly interwoven with the international political economy long before oil revenue: Howing. This history of international involvement can be traced back to the colonial establishmeste of cotton cultivation which had produced local intermediaries for the rising world economy of the 19th century. "The: trajectory since then has slowly led inte the prolonged state of economic, ecologic, social and security crisis still ongoing, interrupesed by periods of relative peiace in the 197()s and oil wealth in the 2()()()s. Foreign indebectuess and trate deficits remained, though. Long gone were the days of the cotton-owed trade surplus of the first postindependence years. This history illustrates how the process of global capieal accumulation subjects local social relations to systenic pressures. This also applics to the SPLM, which, beyond its developmentealist agenda, is suldject to a wider political economic imperative that necessarily involves social contradictions inherent in capitalist development per se. However, while 'global' market forces cersainly play a role in understanding the current process of primitive accumulation, carriced out by a ghobal market, intesmational institutions and locial elites, there are also geopolitical aspects that influence outcomes, which is a neglected aspect in many amalyses.

\subsection{Geopolitics}

The most obvious and most commonly refiered to geopolitical aspece in Sudan as well as South Suctan is the effect of competition over the aceess to hydrocarbons, especially between "Wes[ern' powers like the USA and 'A sian' playens like the People's Republic of ('hina. As will be demonstrated in the following section, resource competition alone is insulficicat for explaining the respective Sudan policies of mitor powers. Rather, this section will try to analyse these policies in their historical $\rightarrow$ ococial relation cowards one another to account for a multitude of global and regional dynamics determining the actions of extermal powers in the region.

Historicially, geopolitics has always constituted a strong component of the history of elie regrion. This reached from the long-lasting Egyptian influenci: and domination to the ()etomian Empire's tributary relation (or 'Jurkiyya) to the 13ritish Empire. While these relations of domination were formalised, post-colonial independence suggested a degree of self-detemination that is not necessiarily reflected in the scope of action provided to the respective leaderships in Juba and Klhastesum. In other words, even without mobilising a neo-Marxist vocaloulary of 'meo-Imperialisu', 'ne(o-colonialism' or 'Empire', geopolitical social velations frame the past and fiture in the two Sudaus alike.

\section{The United States of America}

From today's vantage point it seems difficult to believe that Sudan was a key US ally in the region during the Cold War. It shows, however, the malieability of global social relations, known as geopolitics, and the value in analysing those. This historic involvement is reflected in the key contribution to the (.PA. Arguably, the United States contimues to be a derermining factor in the future of both Sudans. Today's US forcign policy at the Horn of Africal is no longer characterised by Cold War strategising, however, but by the 'war sm terror'.

The (ieorge W. Bush administration's 'strategic philanthropy' (Banes 2()(05: K2; Huliaras

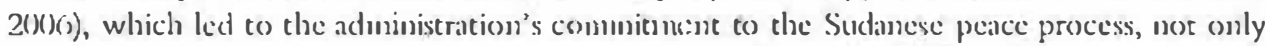
came about as a spontancous reaction to the terrorist attachs on the USA on 11 September 2()() t $(\% / 11)$ but is historically rooted in a long history of involvement in the Sudan (Mandani 2()()); Woodward 2(n)(y). Regardless, the strong US position providing the leverage necessary to end 
the war was effected not by a long-term post-Cold War stritegy for East Afica, aiming at installing a 'client state', but rather by the inadverteut combination of Cold War legacy commitments. like those to Uganda and Ethiopia, the perceived imperatives of the war on terror and the rise of the evangelical right in the USA.

'I lhe end of the exterial "necessity' of the (:old War had initially left US policy-makers in a state of disoricutation towards the whole of Afica but especinlly in a region as geopolitically sensitive as the Horn. This is evideneed by the aborted Sommalia mission followed by a wider disengagement under President Bill Clinton. While West, (entral and East Africa, despite all their confliets and instability, were arguably more subject to the influence of their respective former colonial powers, the Hom's geopolitics are more fragmented. The proximity to natural resources and mar itme energy routes makes it subject to competition by independent rising post-colonial powers. Notably this applies to the mostly hydro-political relations between Egypt and Ethiopia in the immediate neighbourhood and, in the periphesy, Saudi Arabia, Iran, lsracl and until recently Libya.

It is preciscly these imbitions that had also put them at the centre of (old War dynanics, with such dramatic implications for the 'intenal' social relations in Sudan (Mandani 2()())). Apart from these rivalries the region adjacent to the enemgy-rich Middle East is of natural geostrategic interest to powers aiming at global reach, but also to smaller middle powers active in the enviromment. For example, while being geographically fur removed, Sudan has always played an important part in the Arab-Isracli conflict, prompting longlasting Isracli involvement in East Africa and in Uganda especially. Similarly, Sudan currently has to balance its declared fiendship with lran with the long-standing financial and religious influence of the more proximate Saludis, who look at this 'friendship' with disapproval.

Additionally, no clear regional hegemon has emerged, providing ample 'room to manocuvre' to all players on the chessboard, including any regine Khartoum has produced (Marchal 20)](): 81). Due to the geopolitically ambiguous post Cold War situation, the US had difficultics "in defining an overarching set of national interests' which could have provided the context for a more interventionist policy (van de Walle 2009: 1). Consecpuently, the Clinton administration's policy, preoccupied with peace-making in the 13alkans, was one of 'retrenchment and timidicy' with the active discouragement of intervention in the R wandan genocide constituting a possible low point (van de Walle 20)(5): 2). 1)espite ies ineffiectiveness, the 13ush canpaign still criticised (:linton for being too commited to the continent Paradoxically, Bush thus turned out to be much more pro-active in Africa as a whole, starting with his commitment to fighting HIV/ AIDS. If the increase in aid had come to miny as a surprise, the increased engagement culminating in the 2()(57 creation of a dedicated command for the contincent Aficica Command (AfikIC:()M, without Egypt) can be seen as part of a redefinition of US interests in the continent fost-i)/11. As opposed tottic Middle East, the Africa engagement did not suffer from a portrayal as unjustifiable neo-colenialism. Starting from what van de Walle calls 'ad hoc humanitarianism' it was especially the success of the (:PA that led many commentators, including many vocal critics, to describe the administration's record in Africa as a unipue suceess in stark contrast to the rest of the 13ush legacy (Mandani 2()11; van de Walle 2())()9: (6)).

White the war on terror began focusing more directly on Somalia, the continued US interest in the regriou also includes both Sudans. South Sudan as a reliable ally is supported by the ongomg militarisation of US A ficica policy, cpitomised most clearly by the launching of the (:ombined Joint Talks Force - Horn of Africa (C.JTF-H()A) in response to the threat of Al Qaeda and affiliates in the region in 2()()2, but also by direct and indirect military aid as declared in President Barack ()bama's latest budget plaws futerestingly, militarisation and aid became intenningled under these, circumstances, so that AFRIC COM now manges one-fifth of the (US aicl butget to Africa (van de Walle 2(1)9: 13). Helations with Khartoum away from the public image are not in any case as 


\section{Clemens Holimann}

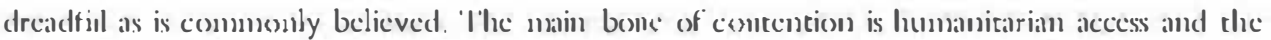
face that the USA has not anoved Khartom from the list of states sponsoring terrorism, as initially promised. More gencrally, though, the N(XP is ule stranger to Washingtom. After the

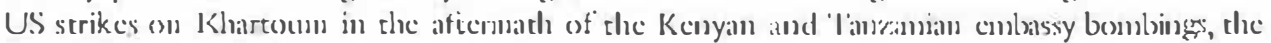
Ne.' keakership has demonstiated a highly co-operative spirit, especially with regard to intelligenece co-openinion, which is comsidered vital to US operations in Somalia. ()fficial US policy, in particular those pants of the Repulblic:an party influcueced by the evangelist right and those parts of

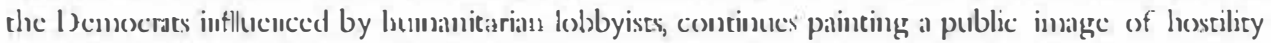

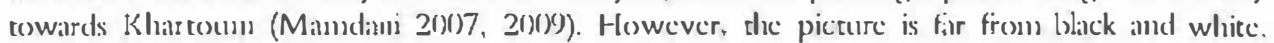
Similarly, while the US role, especially in the drafting of the (:PA, is crucial, its actions have to) be enderstesod in relation to other powers' actions and events in the region and globally.

\section{The People's Republic of China}

[3y contrast, (:hina's involvement in both Sudans is frequently reduced to pure energy security policy (Molan and Power 2()) ()8). While the heavy invesuncenes in Sudan's oil inderstry certainly deternine (:hinese (iovermment's interests in the region, this does not come in the form of a strict anti-Ansericinn support of l3ashir and the Ne:P? (iiven that $71 \% \%$ of proven rescrves are in the south, Juba is an equally important partner for (hinia. With independence and the strong tie:s between the SI'LM and the US, comperition for matural resources and influence is certainly a firctor, though the concerec nature this competition maly take is unknown. Most likcly it will

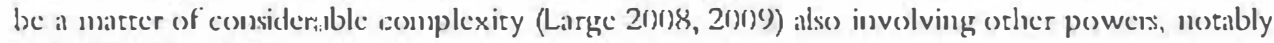
India (Narlikitr 2()) (1)).

Similar power constellations can be found in broader geo-strategric terms beyond the issuc of encrgy security. (:hina's growing extcrisal trade reguires securing global routes, a policy which has been articulated in the so-called 'String of Pcarls' strategy, of which LAPSSE']' could be a part. While this could just represent legitinate and recognised maritme trade interests (Khurama 20()8), it mighte e(pually lead to compertition with lndia and the USA. Militasy and security implications are fir fiom clear, though. In any casce, the fact that it provides room for speculation is sufficient to make the String of Pearls relevante. For even if there is ne "hard' security isste at stake, the stratcgy exists at least as a perception, which in tum might influence naval policies of other powers, like the USA ((icre 2()()5; Pelirson 20)(3)).

\section{The dialectics of geopolitics}

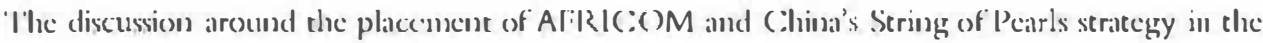
Indian ()e ann provides two indicaters of what underlies the respective (ircat Power strategies in the region beyend resource acecss. However, these should not be seen as two 'tunnel visions', blindly followed by these powers independene of their environuent. Nor should analysis be limited to a 'global' comperition between Beijing and Washingtons: Anore likely, the two powers are precoccupied with finding a lucw modess vivendi allowing cach the continuation of their respecrive strategics of accumbulation This also includes the thus farr highly fiagile post(PA intro-Sudanese relations, which are to be strengthened insteid of contributing to destabilising the region with (ircat Power competition. In fitce, most states will be concerned with pose (PA stability - a desire that has become even greater at a time characterised by an increasing sense of post-revolutionary volatility and unpredictability in the Arab world.

I'his shore postrayal of the complexity of global political economic and geopoliticial relations is by 100 meims exhatustive. It simply goes to show that policy decisions are not taken in a 
vactum, purely etetermined by what Robert Putuam once famously called 'two-level games' ('butnam 1988). Rather, they are the outcome of a complex web of social relations, "domestic', 'international' and 'global' in secope, sometines part of a wider policy, but also sonetimes ad hoc reactions to other actors and emerging structures. (icopolitics is therefore beter understood as the dialectical relationship between different historically and geographically specific forcign policies emerging from a social substance, rather than purely structurally generated socially cmpty (ircate Power competition (Waltz 1979). While competition is part of this dialectic, including the compctition over resources for profit, it might equally follow difficrent imperatives in different situations. It is therefore the dialectical relationship of powers and the unintended conseguences this relationship has generated that constitute the gecopolitical structure into which South Sudian was born. This is what delimits the new country's scope of action. Within the dual structures of global unarkets and a pre-existing inter-state system South Sudan can adapt, react, influence and contribute, but it camses determine the shape of its fietere entirely independently.

\section{Conclusion}

An historical peripective on the contemporary process of primitive accumulation reveals viutous dialecticial rebationships determining the paatene and seope of development in the Sudan and the ncwly independent South Sudan. The finst of these relationships is that with its own history. Historically constituted social - productive - relations continuc to infuence the current trajectory of both Sudans. This is not to argece in fivesur of a path dependency, however, but rather that any analysis of the contemporary policy dilemmass requires a thorough scarch for their historical origins. Second, fitom a classical Marxist perspective, how the relationship between capital and direct producers develops is crucial for the future of production and, lence, weileh creation. This relatiouship needs careful calibration, ustally by the state when undergoing cappitalist development. In other words, the establishument of a waged labour force as the basis for a capitalist growel regime will have to separate direct producers f(om their means of production, implying a tremendous social transformation that reguires carcful negotiation, Thisd, the establishment of a private property regime is subject to similar conditions with regards to land rights. How the carefully crafted South Sudanese land policy will be implenented is crucial in this regard, frumet a clearly identifying local agency in this process is problematic as it is subject to an increastingly volatile global regime of capitalist accumulation. This regime of accermulation is in tenn itself cmbedded within global and regional geopolitical systems. Political decisions directing the future path of South Sudanesc slevelopurent are therefore elomemselves part of a 'global'/'geopolitical' dialectic, the complexity of which is sometimes difficult to penctrate anblytically. Fiftly chese difficultics should not obscure the view on an intra-clite (ompetition, carried ont locilly and regionally as well as giobally over the sources of surplus, with arable land being second only to oil in its desirability. Hevelopuncutal contradictions arc thus reproduced locilly as well as globally, specifically within the agricultural/land developmente sector, reaffirming the view that 'primitive accumsulation' has to be secu as a permament, rather than finitc, process.

In the me;ntinc, development in South Sudan, agnicultural and otherwisc, remains in its infancy. What some might sec as a 'privilege of backwardness' provides incentives for devising 'mega projects' for others. This applics in particular when it comes to addressing the paramome issues of food security and pressures to diversify the economy awaly from hydro-carbons. Flowever, the lesson that South Sudan can lean form its fonner northeres fox is that bejeprs-i jects, more than officring valuable services for the population or a yuick fix as ford security and other problems, more than anything officr high levels of surplus to investor:, which is frecguently 


\section{Clemens Hoffmann}

siphoned off by markets. (appital does not necessarily benctit the locial poptelation, who have to buy back services at infllated rates te accommodate investors" expectations. Historical and contemporary experiences in the giobal noreh and elsewhers in Africa suggest that develogumene in big projects involving foreign interests can have detrimental effects on communities (appital thus accumbulated, however, will find a way to turn profitable, cepecially if instability peisists and the institutions of the new state remain weik. Thus, while big projects might secon an intuitive reiaction to the current situation, smbill-scalle commonnity-based projects nevertheless offer more stustainable forms of development, a more direct return on the investment, but also a sateguard against the outbreak of similar patterns of conflict. This applies to the expansion of agricultural prodection as well as to hydro-enginecring and other big projects.

While this chapter has focused on cuestions of the relationship between band, social power and the conviromusent in - by now - two countries, it has to be recognised that the sources of war and instablility are equilly locited within the globally and historically constituted social relations bricfly outlined here.

\section{Notes}

1 Parts of this research have been conducted uneler the EU Jilp (:Lle:() project, for detiils sec: www. dico.ong. The author is grateful for the support.

2 Bernaliu (2) Ii: 8.3) quotes Artick 5 of the SI'LM legislation No. 1 of 1983 at lengeth:

The Manxist-Leninist movement known as Sudan's Deeple's Liberation Movement shill be the sol: people's pofiticial organisation estiblished in the interest of the oppressed working masses of the: Sudine people to liberate the coustry from the oppressive, compt and reactionary bourgeois govermencent of Khartoum.

Thus, in the early stages of the seruggle, arguably still dominated by the imperatives of the Cold War, dx. Sl'LM actopted an anci-ciapitalist, rateler than anstinorthern/Aril), lannguage.

3 This point has becin macke by various social theorists, from within beth Marxist and Weberian tradi(ions: Wood (2)()2); 'lilly (199)(1)).

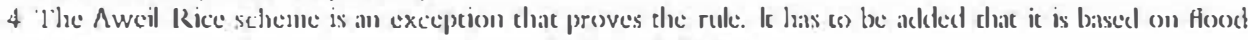
irrigation :and in the early stages of donor-funded rebabilitation.

5 Statements of this natur: are feequently aired by Sobeh Suclanese politicianss and Vice-1'resident Ricek Makthar in particuliar. There is a concerted policy plan backing up such ptans, as evidenced by the

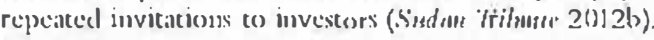

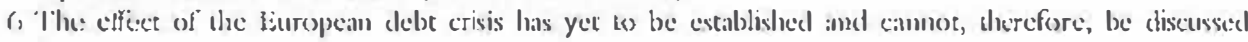
here.

$7 \%$ me most striking example of its bather nuanced Sudim policy is (:hina's abstention when dac Security (ouncil Resolution refermed the 1)arfur War (:rimes to the IC:C: in 20(3)5. Notably, the USA cast the simne vote along with Brazil and Mlgs:ria, while Russia and the Lurepeam permanent UN Security (ouncil (UNSC: numbers voted in fivour.

\section{References}

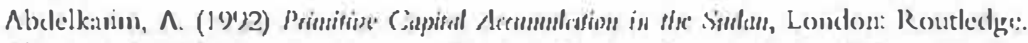

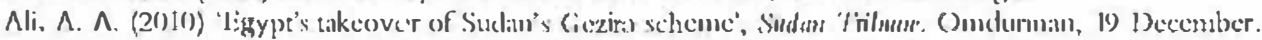



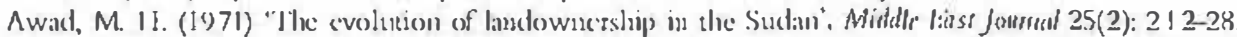

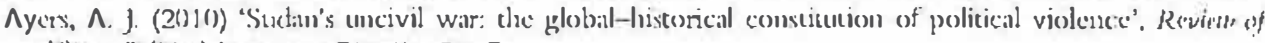
Africum Politiral licomomy 37(124): 15,3-71.

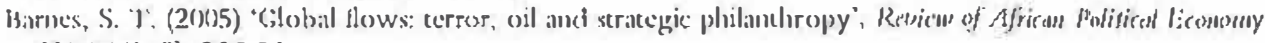
$32(104 / 1(15): 235-52$.

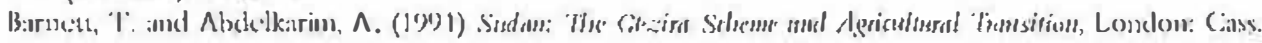




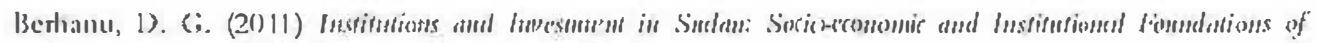

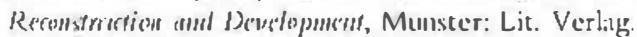

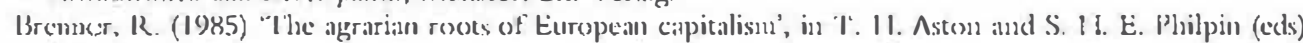

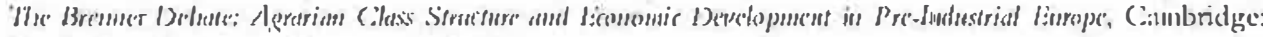
C:illuhridge University l'rexs, pp. 21.3-328.

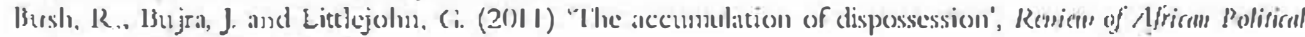
liтиони $38(128): 187-62$.

1) Angelis, M. (2()()4) 'Separating the doing and the decel: capital and che contemusus character of enciosures', Histerical Maferialism 12(2): 5787.

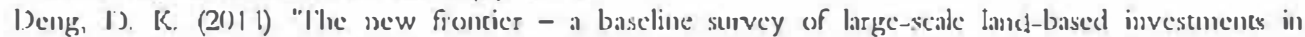

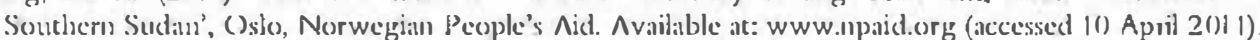

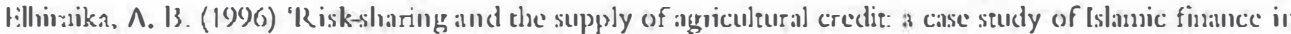



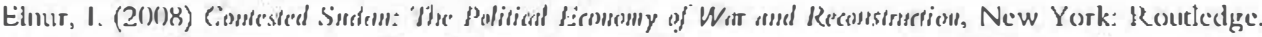

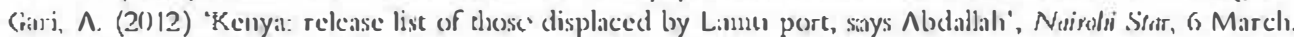

(;ertz, 13. (20)(5) 'China builds up strategic seal lanes', Washington fimes, 18 January.



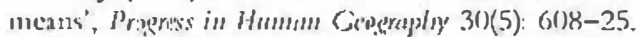

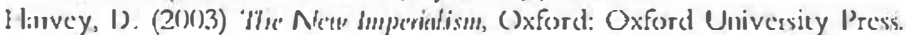

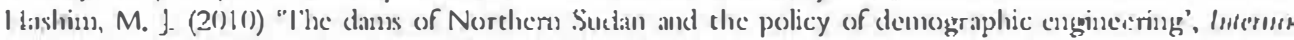



I luliaras, ^. (2()()6) 'Evangelists, oi] connanies, and terrorists: elue Bush administration's policy towards Sudiur, Orbis 5()(4): 7(1)-24

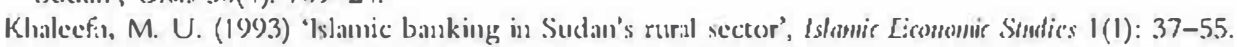

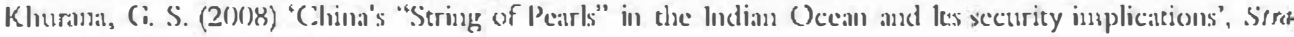
tépir Amoilysis: 32(1): 1-39.

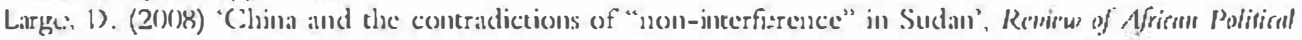
Viromsmiy $35(115): 93-11)($ )

- (20)(5)) 'Chin:1's Sudiun engagement: changing Northen and Soushem political trajectories in pe:ace and war', The (:hina (2utrikerly 19)(1): 611)-23.

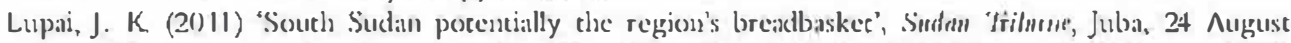

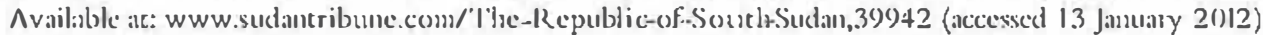
_-(2)12) 'South Sudan: agriculture altermative to oil for development', All, $\mathrm{A} / \mathrm{rica}$.rom. Available at: http://allafrica.com/stories/2012()22 1 1323.htul (accessed I ^pril 2()12).

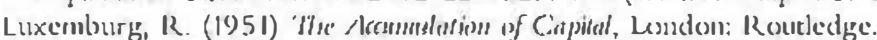

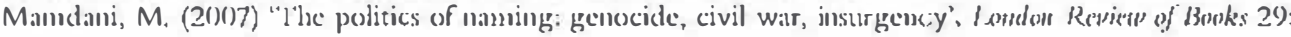
$5-8$.

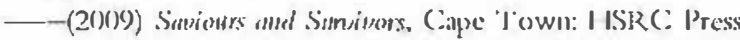

(2()II) 'South Sudiul: rethinking citizenship, sovereignty and sedf-detemination', Pambazmken Nemes $527(1) 5-1) 4)$

Marchal, R. (20)(1)) "I'he regional dimension of Sudinese politics', in I leinrich IBöll Stiftum (ed.) Suedm No liasp Wor, sllecsel, Berlin: 1-1. [3. Lioundation, pp. 79-96."

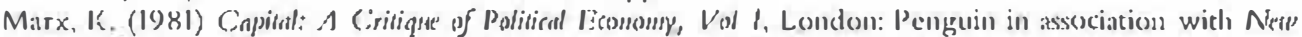
Ioff Resileme.

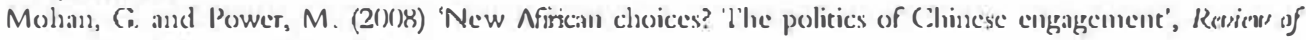
Africum Political licconomy 35(115): 2.3-42.

Mosley, J. (2012) 'Peace, bread and land - agricultural investments in Ethiopia and the Suct:ans", (hathan flouse briefing paper. London: (:hatham House.

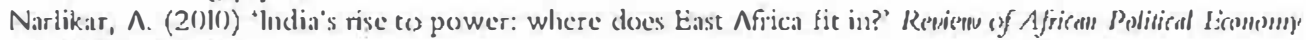
$37(126): 451-(, 4$

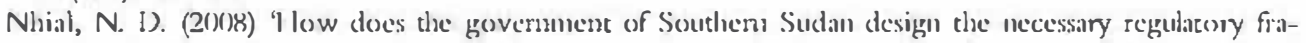
mework to attrace 19 ) | inte the agricultural sector?' master's thesis, ('entere for Energy, Petroleum, and Mincra] Law and Policy. Dundec: Univerity of 1)undec.

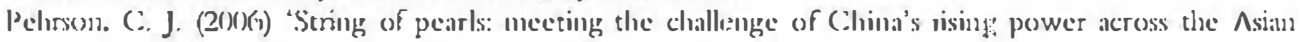
litcoral', Strategic Studics Institute US Anny War Collegge.

Putnam, R. 1). ((988) ¿Diplomacy and domestic politics: the logic of two-level gimmes', Intermutional ()rganization 42(().3): 427-6(). 


\section{Clemens Hoffmann}

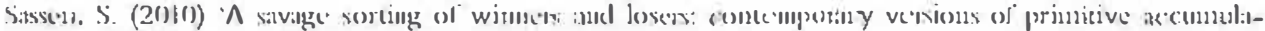

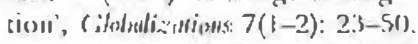

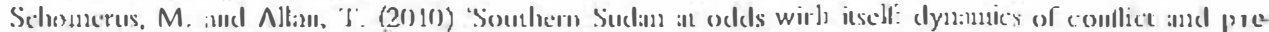

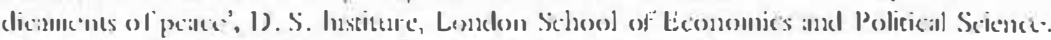

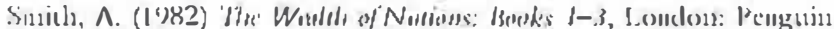

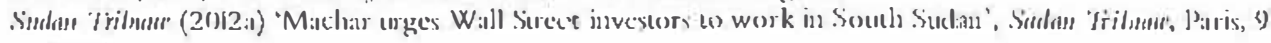
March.

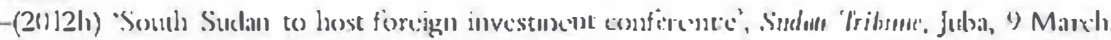

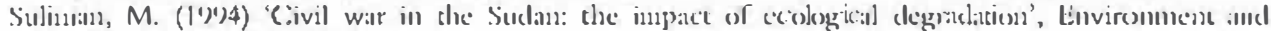
(imilict Projicte (LNC:C) $\left.1^{2}\right)$

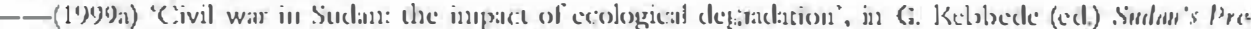





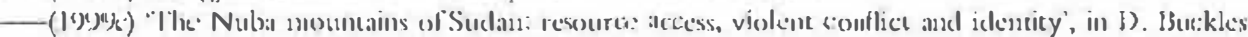

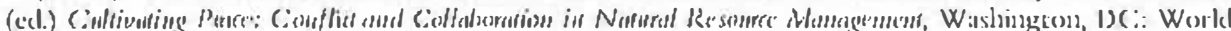
13:11,k.

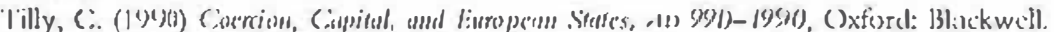

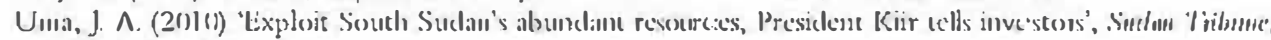
Julia, 3 ()etoluer.

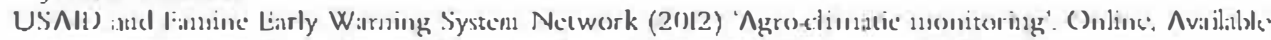

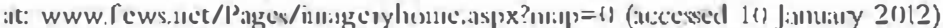

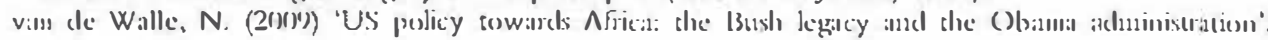
Africull Alfieirs (1)9(4.3:1): 1-21.

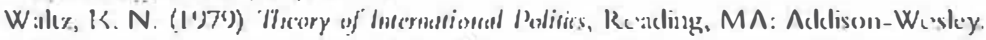



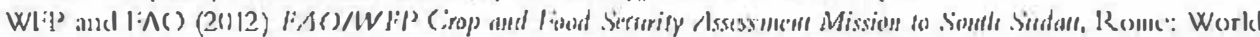

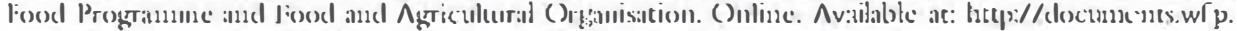

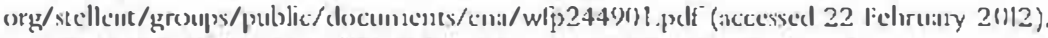

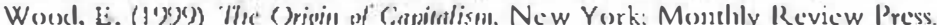

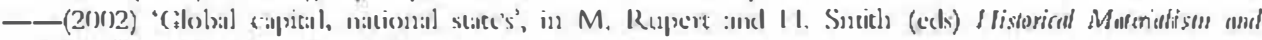
Citolualisurion, London: Koutleclege.

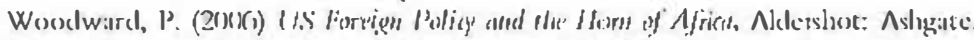

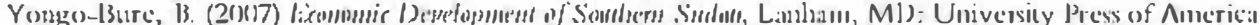

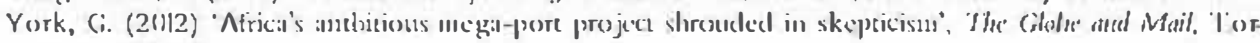
(ollle), o Mirrits. 